\title{
АЕРЖАВНА САУЖБА
}

\author{
УДК 354:378 \\ DOI https: / /doi.org/10.32840/pdu.2-2.38
}

C. A. Мороз

кандидат наук з державного управління, старший науковий співробітник навчально-науково-виробничого центру Національного університету цивільного захисту України

\section{КОМПЕТЕНЦІЯ ДЕРЖАВИ У ЗАБЕЗПЕЧЕННІ КОНТРОЛЮ ЯКОСТІ НАДАННЯ УНІВЕРСИТЕТАМИ ОСВІТНІХ ПОСЛУГ: АНАЛІЗ ДУМКИ СТУДЕНТІВ КИТАЙСЬКИХ ЗВО}

За результатами аналізу змісту Стандартів і рекомендацій щодо забезпечення якості в Європейському просторі вищої освіти було з'ясовано можливість сприйняття держави на рівні одного з основних стейкхолдерів процесу забезпечення якості вищої освіти. Переважна більшість наукових пошуків щодо визначення компетенції держави у забезпеченні контролю якості надання університетами освітніх послуг була зосереджена на дослідженні особливостей функціонування англосаксонської та європейської континентальної систем вищої освіти та була здійснена переважно з використанням суто теоретичних методів наукового пізнання. Такий вектор в організації наукових досліджень залишив поза увагою вчених моделі організації вищої освіти найбільш розвинутих країн Східної Азії. Водночас результати аналізу змісту та практики функціонування таких моделей мають неабияке значення для системи вищої освіти України та можуть бути використані для вдосконалення механізмів державного управління якістю вітчизняної вищої освіти.

Реалізація потенціалів міжнародного співробітництва та використання практичних методів наукового пізнання дозволи автору публікації провести опитування студентів Інституту міжнародної та порівняльної освіти Пекінського педагогічного університету (Китай) та з'ясувати їх думку щодо потужності державного контролю за якістю надання ЗВО освітніх послуг. Результати аналізу отриманих відповідей свідчать про той факт, що у межах китайської моделі організації системи вищої освіти держава є найбільш компетентним та впливовим суб'єктом в системі забезпечення якості вищої освіти. Серед опитаних лише 5\% респондентів підтримують думку про те, що держава не повинна здійснювати жорсткий контроль за якістю вищої освіти та діяльністю університету. Зі свого боку, 95\% переконані у тому, що держава повинна здійснювати жорсткий контроль за якістю надання університетами освітніх послуг. Майже кожен п'ятий з опитаних (22\%) дотримується думки про необхідність запровадження жорсткого державного контролю за забезпеченням університетами якості освітньої діяльності та якості вищої освіти без врахування принципів університетської автономії та академічних свобод. Стаття містить обгрунтування отриманих результатів через призму окремих історично-культурологічних та суспільно-політичних особливостей розвитку Китаю. Крім того, стаття містить висновки щодо можливості використання досвіду Китаю під час опрацювання напрямів удосконаленні змісту та практики використання механізмів державного забезпечення якості вищої освіти.

Ключові слова: державний контроль за якістю вищої освіти, система вищої освіти Китаю, опитування китайських студентів, стандарти якості вищої освіти, механізми державного управління.

(C) Мороз C. A., 2019 
Постановка проблеми в загальному вигляді та їі зв'язок із важливими науковими а6о практичними завданнями. Проблематика забезпечення якості вищої освіти, з огляду на свою неабияку значущість в системі суспільно-політичного та соціально-економічного розвитку держави, все далі частіше ідентифікується суб'єктами інституту держави та суспільними інституціями на рівні пріоритетної для свого вирішення. На міжнародному рівні відповідні питання набули своєї актуалізації у межах Глобальних цілей сталого розвитку 2030, інституалізація норм яких відбулась 25 вересня 2015 року у межах Резолюції Генеральної Асамблеї $\mathrm{OOH}$. Серед сімнадцяти визначених Резолюцією цілей, $\epsilon$ у тому числі й ті, зміст яких прямо чи опосередковано пов'язано з питаннями забезпечення якості вищої освіти, а саме: якісна освіта; гідна праця та економічне зростання; промисловість, інновації та інфраструктура; мир, справедливість та сильні інститути (четверта, восьма, дев'ята та шістнадцята за нумерацією ООН цілі). Серед завдань Глобальної Цілі як «якість освіти», $є$ у тому числі й ті завдання, зміст яких пов'язано з «гарантуванням отримання усіма, хто навчається, знань та навичок, необхідних для сприяння сталому розвитку <...>» та «побудови та модернізації закладів освіти <...>» [1]. На державному рівні проблематика забезпечення якості вищої освіти позиціонує серед пріоритетних до вирішення завдань Уряду, визначення яких відбулось у межах Середньострокового плану пріоритетних дій Уряду до 2020 року. Автори програмного документа цілком слушно ідентифікують проблематику забезпечення якості вищої освіти в контексті планової цілі «Розвиток людського капіталу», визначаючи відповідні питання в контексті заходів реформування освіти, а саме: 1) створення нових освітніх програм відповідно до нових стандартів вищої освіти; підвищення рівня та оптимізація результатів наукової та академічної діяльності, підтримка процесу ствердження академічної доброчесності у вищих навчальних закладах та наукових установах; 2) забезпечення ефективної взаємодії представників наукової громадськості, органів виконав- чої влади та реального сектору економіки у формуванні та реалізації єдиної державної політики у сфері наукової та науково-технічної діяльності; збільшення частки грантового фінансування у загальному обсязі державної підтримки наукових досліджень і розробок, що сприятиме підвищенню мотивації наукових працівників до участі у відкритих конкурсних відборах проектів, що фінансуватимуться завдяки грантовій підтримці Національного фонду досліджень, та формуватиме реальну альтернативу продовженню молодими вченими своєї наукової кар'єри за кордоном [2]. Вирішення цих завдань неможливо уявити без визначення компетенції основних суб'єктів забезпечення якості освітньої діяльності та якості вищої освіти. Відповідно до норм Стандартів і рекомендацій щодо забезпечення якості в Європейському просторі вищої освіти (ESG) до таких суб'єктів (стейкхолжерів) відносять «всіх учасників (суб'єктів) у межах закладу, включно студентів і персонал, а також зовнішніх стейкхолдерів, таких як працедавці та зовнішні партнери закладу» [3, с. 7]. Беручи до уваги той факт, що до «зовнішніх партнерів закладу» поряд з Європейською асоціацією забезпечення якості вищої освіти (ENQA), Європейським союзом студентів (ESU), Асоціацією університетів Європи (EUA), Європейською асоціацією закладів вищої освіти (EURASHE) тощо входять у тому числі й інституції ринку праці та держави, вважаємо за необхідне зосередитися саме на визначенні місця та ролі держави у забезпеченні якості вищої освіти.

\section{Аналіз останніх досліджень} і публікацій, в яких започатковано розв'язання даної проблеми, на які спирається автор. Проблематика функціонування та розвитку системи вищої освіти, рівно як і питання забезпечення ії якості, не $\epsilon$ принципово новим напрямом в організації наукових пошуків. Відповідні напрями в організації досліджень були обрані фокусом наукової уваги С.М. Домбровською (проведено аналіз теоретичних аспектів розв'язання проблем державного управління інноваційними процесами в системі вищої школи [4]), М.Н. Курьком (розглянуто проблематику функціонування 
системи державних органів, органів місцевого самоврядування та громадського самоврядування щодо управління сферою освіти [5]), В.I. Луговим (визначено умови ефективного функціонування Національного агентства із забезпечення якості вищої освіти України [6]), О.К. Любчук (висвітлено теоретико-методологічні основи механізму державного управління функціонуванням і розвитком неперервної освіти в Україні [7]), С.В. Майбородою (обґрунтовано сутність та закономірності структурування, функціонування, еволюції управління вищою освітою [8]), В.М. Морозом (з'ясовано переваги та недоліки окремих моделей підготовки науково-педагогічних кадрів, а також визначено напрями вдосконалення механізмів державного управління відповідною системою $[9,10])$, В.М. Огаренком (розглянуто методологічні основи державного управління системою освіти та запропоновано напрями вдосконалення механізму кадрової політики на ринку освітніх послуг [11]), В.П. Садковим (досліджено механізми формування освітніх державних стандартів, розробки концепції щодо вдосконалення якості підготовки фахівців цивільного захисту у сфері вищої освіти [12]) та інших вчених. Серед останніх наукових досліджень слід звернути увагу на ті з них, які були виконані С.А. Вавренюком, А.В. Вербицькою, П.І. Гаманом, Л.М. Грень, Л.В. Жук, С.А. Калашніковою, Л.М. Калініною, О.Є. Кузьміним, Т.О. Лукіною, С.В. Майстром, М.Я. Яструбським та іншими дослідниками.

З огляду на свою актуальність, як для теоретико-методологічного забезпечення розвитку наукового знання щодо державного управління освітянською галуззю, так і для практики державного управління системою вищої освіти, питання забезпечення 3ВО якості освітньої діяльності та якості вищої освіти, є традиційним предметом обговорення у межах наукових дискусій під час роботи науково-комунікативних заходів. Серед останніх науково-практичних конференцій, тематична спрямованість яких була пов'язана з пошуком напрямів вдосконалення змісту та практики функціонування системи вищої освіти, слід виділити: IX Міжнародну науково-практичну конфе- ренцію «Управління в освіті» (04-05 квітня 2019, м. Львів - Національний університет «Львівська політехніка»); Всеукраїнську науково-практичну конференцію з міжнародною участю «Освітологія - 2019. Забезпечення якості вищої освіти в університеті: рух України до Європейського Союзу» (24 квітня 2019, м. Київ - Київський університет імені Бориса Грінченка); Міжнародну конференцію «Сучасна вища освіта: реалії, проблеми, перспектив» (14-15 травня 2019, м. Кременчук - Кременчуцький національний університет імені Михайла Остроградського); Міжнародну конференцію «Розбудова системи забезпечення якості вищої освіти в Україні» (11-12 червня 2019, м. Київ - Міністерство освіти та науки України та Національне агентство із забезпечення якості вищої освіти) тощо. Не дивлячись на достатній рівень наукової уваги до розв'язання наукових завдань та розв'язання проблем державного управління функціонуванням і розвитком сфери вищої освіти, окремі напрями відповідної проблематики все ще залишаються відкритими для подальших наукових пошуків.

Виділення невирішених раніше частин загальної проблеми, яким присвячується означена стаття. Питання участі держави у забезпеченні якості вищої освіти, з огляду на їх складність та багатогранність прояву, можуть бути розглянути через призму відразу декількох порівняно самостійних напрямів. Наприклад, контекст вище згаданих Стандартів визначає можливість формування таких векторів в організації наукових пошуків, як: зміст та практика реалізації державної політики щодо забезпечення якості вищої освіти; участь органів публічного управління у процедурах розроблення та затвердження програм підготовки спеціалістів; забезпечення державою дотримання ЗВО принципу студентоцентрованого навчання, викладання та оцінювання; визначення норм та процедур визнання досягнень студентів та їх поточної та підсумкової атестації; встановлення професійно-кваліфікаційних вимог до персоналу який залучається до викладання у 3ВО; вдосконалення системи державної підтримки студентів та розвитку навчальних ресурсів; інформаційно-аналітичне 
та матеріально-фінансове забезпечення державою функціонування та розвитку системи вищої освіти тощо. Безумовно, кожен з цих векторів, зі свого боку, має достатньо розгалужену за напрямами організації наукових пошуків систему наукових досліджень, складність якої обумовлюється, як різноманітністю наявних для аналізу світових моделей організації систем вищої освіти, так і необмеженістю доступного до використання вченим інструментарію наукового пізнання. Не дивлячись на багатогранність окресленого нами об'єкту наукової уваги, переважна більшість, принаймні вітчизняних наукових досліджень, зосереджена на розгляді питань публічного управління сферою вищої освіти у межах англосаксонської та європейської континентальної систем вищої освіти та переважно з використанням суто теоретичних методів наукового пізнання. Цілком очевидно, що за таких умов достатньо вагома за своїм змістом частка характеристик об'єкту (предмету) наукової уваги залишається за межами фокусу досліджень вчених. Проведений нами аналіз переконливо свідчить про те, що англосаксонська та європейська континентальна моделі організації систем вищої освіти, які були свого часу були обрані профільними органами публічного управління України за основу для вдосконалення національної системи вищої освіти, поступово втрачають своє лідерство на міжнародному ринку освітянських послуг. Наприклад, за результатами аналізу рівня представництва університетів США, Китаю та Сінгапуру у межах умовної групи ТОП-50 визнаного науковою спільнотою міжнародного рейтингу QS World University Rankings, можемо констатувати той факт, що у період 2016-2019 кількість американських ЗВО збільшилася лише на $5 \%$, в той час як кількість 3 ВО з Китаю та Сінгапуру зросла на 50\% $[13 ; 14]$. Не дивлячись на більш чим відчутну динаміку зростання авторитету китайських та сінгапурських університетів на міжнародному ринку освітянських послуг, дослідження змісту та практики функціонування відповідних систем вищої освіти, рівно як і механізмів державного управління розвитком сфери вищої освіти та забезпе- чення її якості, на жаль, не набули свого достатнього розвитку в роботах вітчизняних вчених. Окремі аспекти прояву цієї проблематики були нами розгляну під час попередніх напрямів наукових пошуків $[15 ; 16]$, а отже ця публікація повинна сприйматись як їх логічне продовження.

Крім того, слід звернути увагу на той факт, що на рівні світового наукового дискурсу питання функціонування та розвитку систем вищої освіти найбільш розвинутих країн Східної Азії, постійно позиціонують у колі безпосередньої уваги вчених. Достатньо звернути увагу на наявність серед наукової періодики спеціалізованих наукових видань, а саме: Chinese Education and Society, Frontiers of Education in China, International Journal of Chinese Education та інші наукові видання. Аналіз змісту розміщених у цих виданнях публікацій свідчить про зосередження дослідників на загальних питаннях функціонування системи вищої освіти Китаю, без звернення до проблематики тих чи інших аспектів (характеристик) прояву системи вищої освіти та її якості поданих через призму думки студентів, як безпосередніх, з одного боку, замовників освітянської послуги, а з іншого - учасників навчальної комунікації. Відсутність таких публікацій не лише не сприяє розвитку науковометодологічного підґрунтя для вирішення цілей та дотримання принципів згаданих вище ESG (наприклад, сприйняття студентів на рівні так званих стейкхолдерів, а також забезпечення державою дотримання ЗВО принципу студентоцентрованого навчання), а і порушує архітектоніку розбудови наукових пошуків (порушення принципу комплексності у розгляді предмету наукової уваги). Отже, з'ясування та аналіз думки студентів, насамперед тих з них, які здобувають вищу освіту у межах альтернативних щодо англосаксонської та європейської континентальної систем вищої освіти, адже саме ці системи все далі частіше демонструють свою спроможність до забезпечення включення чинних у їх межах ЗВО до топових груп міжнародних університетських рейтингів, $\epsilon$ не лише важливим з огляду на розширення кола загальної наукової уваги щодо обраної проблематики, а й актуальним вектором 
в організації наукових пошуків в контексті предметно-об'єктного спрямування державно-управлінської науки.

Формулювання цілей статті (постановка завдання). За результатами аналізу думки китайських студентів щодо місця та ролі держави у забезпеченні контролю за якістю надання освітніх послуг 3ВО, запропонувати напрями вдосконалення змісту та практики використання механізмів державного управління якістю вітчизняної вищої освіти.

Виклад основного матеріалу дослідження з повним обґрунтуванням отриманих наукових результатів. Переважна більшість наявних у межах наукової думки результатів досліджень проблематики функціонування та розвитку тієї чи іншої моделі організації системи вищої освіти, так само як і визначення місця та роль суб'єктів публічного управління щодо забезпечення контролю за якістю надання освітніх послуг, була отримана з допомогою теоретичних методів наукового пізнання. Безумовно, використання цих методів (аналіз та синтез; абстрагування та узагальнення; індукція та дедукція; історичний та логічний методи; ідеалізація тощо) $є$ цілком виправданим для організації наукових пошуків на теоретичному рівні наукового пізнання (постановка проблеми; висування гіпотези; формування та удосконалення змісту теорії тощо). Водночас обмеження інструментарію дослідження суто теоретичними методами, як правило, не дозволяє вченому всебічно дослідити предмет наукової уваги та визначити ті з його характеристик, отримання інформації про які $\epsilon$ результатом використання методів емпіричного дослідження. 3 огляду на цей факт, на етапі збору інформації (фактичного матеріалу) нами було використано метод опитування у формі анкетування.

3 огляду на предмет наукової уваги, у якості респондентів були обрані студенти Інституту міжнародної та порівняльної освіти Пекінського педагогічного університету (Institute of International and Comparative Education at Beijing Normal). Проведення анкетування студентів цього ЗВО стало можливим завдяки реалізації неформальних домовленостей з представниками Університету Тампере (Фінляндія) які на час пошуку нами партнеру в Китаї реалізовували спільний з його університетами проект. Абстрагуючись від пояснення механізму пошуку закордонних партнерів та організації з ними взаємодії, звернемо уваги на отримані нами результати.

Зміст запропонованої до заповнення студентами анкети «Оцінка якості вищої освіти» було складено відповідно до методичних порад С. Садмана (Seymour Sudman), Н. Бредберна (Norman M. Bradburn) та Н. Шварца (Norbert Schwarz) щодо особливостей формулювання питань анкети [17]. Крім того, під час формулювання запитань ми звернули увагу на результати реалізації грантового проекту «Система забезпечення якості освіти в Україні QUAERE-562013-EPP-1-2015-1-PLEPPKA2CBHE-SP: розвиток на основі європейських стандартів та рекомендацій» в частині теорії та практики розбудови анкет щодо проблематики забезпечення ЗВО якості освітньої діяльності та якості вищої освіти [18]. Студентам було запропоновано дати відповідь 18 запитань, з яких 15 мали безпосередній стосунок до предмету нашої наукової уваги. В контексті обраного нами предмету наукової уваги вважаємо за можливе зосередитися на аналізі лише тих з відповідей респондентів, які були пов'язані з визначенням місця та ролі держави у забезпеченні контролю за якістю надання освітніх послуг ЗВО. Результати аналізу отриманих нами відповідей подано на рисунку 1.

За результатами аналізу відповідей респондентів можемо сформулювати такі основні узагальнення.

По-перше, переважна більшість респондентів (73\%) переконані у тому, що «держава повинна здійснювати жорсткий контроль, але без порушення принципу так званої університетської автономії». Така думка студентів загалом відповідає нормам стандартів ESG, наприклад, в частині рекомендацій щодо зовнішнього забезпечення якості вищої освіти, а саме залучення стейкхлдерів до розроблення методології зовнішнього оцінювання якості, а також до процедур ії реалізації на практиці. Вище ми звернули увагу про можливість ідентифікації держави на рівні стейкхолдера, а саме - «зовнішнього 


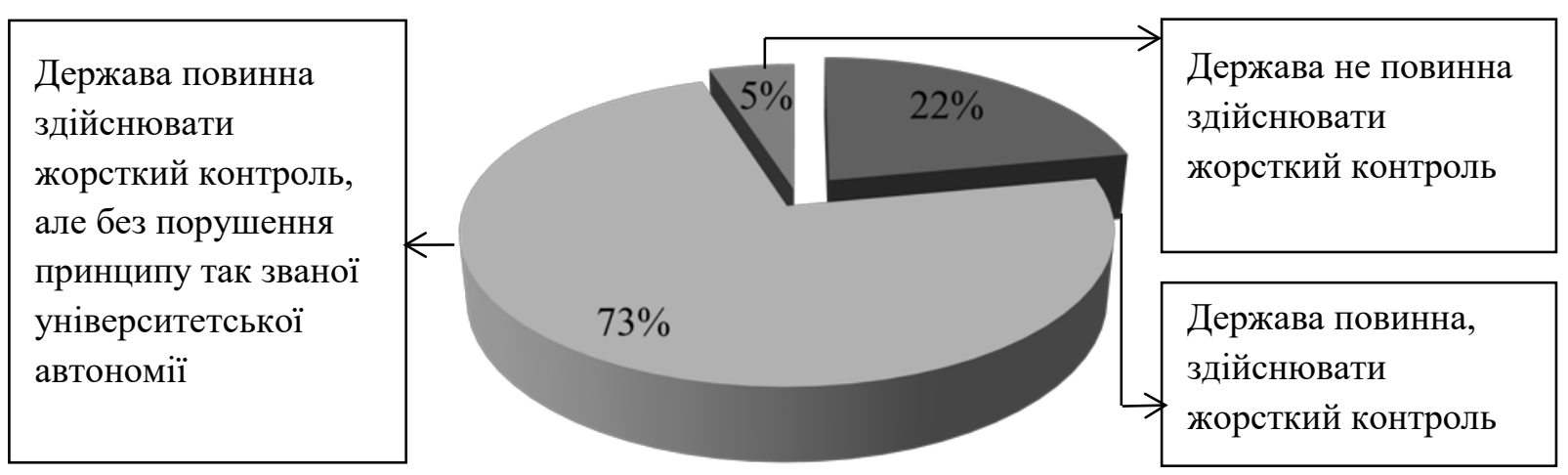

Рис. 1. Розподіл думок студентів ЗВо Китаю щодо необхідності забезпечення державою контролю за якістю надання університетами освітніх послуг

партнера закладу» [3, с. 7; 17]. Крім того, забезпечення державою «жорсткого контролю, але без порушення принципу так званої університетської автономії» може бути пояснена через призму вимог ДСТУ ISO 9001:2015 (ISO 9001:2015, IDT) Системи управління якістю, наприклад в контексті таких норм «орієнтація на замовника» (держава $€$ основним замовником на підготовку фахівців з вищою освітою); «формування політики у сфері якості» (держава є суб'єктом формування та затвердження: стандартів вищої освіти за спеціальностями; ліцензійних умов провадження освітньої діяльності; норм та правил акредитації освітніх програм тощо); визначення «цілей у сфері якості та планування дій для їх досягнення» (державну політику у сфері вищої освіти визначає Верховна Рада України, а реалізують Кабінет Міністрів України та центральний орган виконавчої влади у сфері освіти та науки) тощо. Водночас отримана нами узагальнена думка респондентів на рівні 73\% має достатню вірогідність похибки. Це пов'язано з тим, що зміст принципу «університетської автономії» може мати декілька тлумачень, які різняться не лише за визначенням обсягів та рівню прояву автономії, а у тому числі й за фактом сприйняття феномену автономії загалом. Наприклад, наявна в китайських ЗВО система університетського управління передбачає існування в штаті ЗВО чисельної групи адміністративних робітників, які мають статус державних службовців. Цікаво, що кількість таких робітників у ЗВО майже дорівнює кількості наукових та науково-педагогічних кадрів
[19, с. 84]. 3 огляду на цей факт, виникає питання що саме мають на увазі респонденти коли акцентують увагу на необхідності дотримання державою принципу університетської автономії? Залишимо це питання без відповіді, адже відповідний напрям аналізу дещо виходе за межі обраного нами предмету наукового пошуку.

По-друге, майже кожен п'ятий респондент (22\%) погодився 3 тим, що «держава повинна, здійснювати жорсткий контроль» за якістю надання університетом освітніх послуг. Така позиція студентів може бути пояснена, як через факт участі держави в управлінні університетом (вище ми звернули увагу на частку адміністративного персоналу зі статусом державних службовців в системі університетського управління), так і через призму традицій розвитку системи вищої освіти Китаю, закладених в середині XX століття. Наприклад, з приходом до влади в Китаї комуністичної партії всі заклади вищої освіти були націоналізовані та перейшли під повний контроль держави. Починаючи з 1952 року система вищої освіти Китаю здійснювала свій розвиток за принципами радянської моделі розбудови системи вищої освіти та багато у чому копіювала iї: розподіл ЗВО на класичні, галузеві та спеціальні; державна форма власності 3ВО; жорстка ієрархія в управлінні 3ВО; уніфікація навчальних планів та централізовано затвердженні для використання підручники; стрімке зростання кількості студентів завдяки робочій та селянській молоді тощо. Наслідками реалізації принципів так званої культурної революції в системі вищої освіти стало не лише 
зростання ролі держави у їі розвитку, a i поступове зменшення рівня якості надання освітянських послуг. Тут ми маємо звернути увагу на парадоксальну ситуацію, за якою, з одного боку, держава стає домінуючим (єдиним) суб'єктом управління функціонуванням та розвитком системи вищої освіти, що зумовлює її майже необмежені потенціали в управління якістю вищої освіти (на кшталт радянської моделі), а з іншого, саме держава стає ініціатором зниження рівня вимог до абітурі$\epsilon$ нів. Передбачалось, що зниження вимог до знань абітурієнтів дозволить залучити до університетів представників робочого класу та трудового селянства, тобто осіб 3 «правильною політичною ідеологією». Крім того держава значно спростила процедури формування нових 3ВО та знизила кваліфікаційні вимоги до науковопедагогічних працівників, що у кінцевому випадку дало змогу відкривати «університети» маже при кожному достатньо великому підприємстві. Залишаючи поза увагою аналіз цієї суперечності (держава як основний суб'єкт контролю якості вищої освіти та держава як ініціатор зниження рівня якості вищої освіти), констатуємо той факт, що саме держава відіграє визначальну роль в системі вищої освіти Китаю, а відповідно саме вона може бути розглянута на рівні одного з основних суб'єктів забезпечення її якості.

По-третє, лише 5\% респондентів підтримали думку про те, що «держава не повинна здійснювати жорсткий контроль» за якістю надання університетами освітніх послуг. Такий результат був нами цілком очікуваним, адже традиції функціонування китайської моделі організації вищої освіти не сприяють розвитку академічної свободи та інституційної автономії університетів (саме тому, на нашу думку, частка осіб які схвалюють послаблення ролі держави в системі забезпечення якості вищої освіти, є порівняно незначною). Водночас сам факт існування респондентів з думкою про зниження рівня участі держави в функціонуванні системі забезпечення якості вищої освіти свідчить про демократизацію сфери вищої освіти Китаю, насамперед завдяки імплементації до неї окремих принципів та норм англосаксонської та європейської континентальної систем вищої освіти. За дослідженням Рут Гейхо (R. Hayhoe) є три основні канали експансії західних принципів розбудови системи вищої освіти в систему вищої освіти Китаю, а саме: утворення американськими протестантами-місіонерами, німецькими промисловцями та французькими єзуїтами власних університетів на території Китаю (з 1850 року іноземці, переважно шляхом військового тиску, отримали доступ до суспільно-політичної та соціальноекономічної підсистем Китаю); надання Урядом США стипендій китайськими студентами для отримання вищої освіти за межами Китаю (у 1908 році з коштів отриманих США у якості компенсації за завдані Іхетуанським повстанням збитки було утворено фонд для фінансування здобуття вищої освіти студентами з Китаю за його межами, переважно у США); реформування китайських $3 \mathrm{BO}$ з прийняттям до уваги сучасних глобальних трендів розвитку інституції університету, а також прогресивних концепцій розвитку сфери вищої освіти опрацьованих відповідно до поглядів авторитетних китайських реформаторів (керівник Пекинского університету Цай Юаньпень запропонував до використання у ЗВО так званої гумбольдтської моделі університету з акцентом уваги на університетській автономії та академічних свободах) [20].

Висновки 3 даного дослідження та перспективи подальшого розвитку в цьому напрямі. Отже, беручи до уваги вищенаведене можемо сформулювати такі основні висновки:

1. з огляду на значне зростання рівня представництва китайських 3 ВО у межах топових груп престижних міжнародних університетських рейтингів, китайська модель організації сфери вищої освіти, а відповідно і система забезпечення їі якості, заслуговує на увагу дослідників. В контексті фокусу наукової уваги державноуправлінської науки, предметом аналізу, за відповідним напрямом наукового пошуку, повинні стати: державна політика Китаю щодо розвитку освітянської галузі; механізми державного управління системою вищої освіти; місце та роль основних суб'єктів університетського розвитку 
у забезпеченні якості вищої освіти; темпоральні та просторові особливості розвитку системи вищої освіти Китаю; компетенція та відповідальність стекхолдерів щодо забезпечення ЗВО якості освітньої діяльності та якості вищої освіти. Отримання результатів за цими векторами в організації наукових пошуків дасть змогу опрацювати пропозиції щодо напрямів удосконалення змісту та практики функціонування вітчизняної моделі державного управління системою вищої освіти та забезпечення ії якості;

2. у межах системи вищої освіти Китаю, норми та принципи організації функціонування якої можуть бути розглянуті на рівні альтернативного щодо відповідних елементів англосаксонської та європейської континентальної систем вищої освіти підґрунтя для вдосконалення змісту та практики використання механізмів державного управління освітянською галуззю, інститут держави ідентифікується студентами на рівні основного суб'єкта забезпечення якості вищої освіти. За результатами опитування 95\% респондентів вважають що держава повинна здійснювати жорсткий контроль за забезпеченням закладами вищої освіти якості освітньої діяльності та якості вищої освіти, причому $22 \%$ опитаних переконані у тому, що такий (жорсткий) контроль не повинен обмежуватися університетською автономією та академічними свободами. Отже, у межах китайської моделі розбудови системи вищої освіти домінуючий вплив держави на їі функціонування та розвиток сприймається об'єктом управління (керованою системою) не лише як цілком природне та органічне явище, а і як вкрай необхідне;

3. за умови прийняття досвіду Китаю щодо розбудови конкурентоспроможної системи вищої освіти, на рівні одного 3 елементів системи інформаційноаналітичного забезпечення реформування вітчизняної освітянської галузі, так само як і на рівні підґрунтя для вдосконалення змісту та практики використання механізмів державного управління забезпеченням якості вищої освіти, слід взяти до уваги: по-перше, релігійно-культурологічні та суспільно-історичні особливості взаємодії інституту держави з інституцією уні- верситету (умови становлення та розвитку систем вищої освіти України та Китаю не $\epsilon$ ідентичними, хоча на цім мають достатньо схожі характеристики, особливо в контексті темпоральних та просторових викликів процесів та процедур глобалізації вищої освіти); по-друге, не дивлячись на той факт, що державний устрій, а відповідно і система державного управління Китаю та України мають суттєві розбіжності, проблематика домінування держави у забезпеченні розвитку системи вищої освіти та забезпечення їі якості має ідентичний вектор сприйняття (незалежно від історичного етапу розвитку системи вищої освіти України та Китаю, держава завжди відігравала роль основного суб'єкта управління університетським розвитком);

4. беручи до уваги механізм використання Урядом США отриманої за результатами придушення Іхетуанського повстання контрибуції, а саме спрямування сплаченої Китаєм компенсації до фонду фінансування навчання китайських студентів в університетах за межами країни, вважаємо за можливе запропонувати до обговорення схожий за своїм змістом та вектором дії механізм фінансування здобуття вищої освіти тими громадянами України, які постраждали внаслідок бойових дій на Сході України. Крім того, об'єктом фінансування можуть стати також ЗВО які були переміщені з окремих районах Донецької та Луганської областей. Джерелом наповнення відповідного фонду можуть стати кошти які очікувано будуть надходити у вигляді компенсації за завдану Україні шкоду або кошти від міжнародних організацій. Пріоритетне фінансування державою розвитку тимчасово переміщених ЗВО може стати так званим пілотним проектом в апробації досвіду Китаю в реалізації програмних заходів Проектів 211 та 985 (визначення та пріоритетне ресурсне забезпечення найбільш конкурентних ЗВО для підготовки висококласних фахівців та виведення декількох університетів на топові позиції міжнародних університетських рейтингів). За умови використання цього досвіду ресурсне забезпечення обраних для участі у програмі 3 ВО не може бути зведено виключно до використання коштів отриманих Україною у вигляді компенсацій 
та коштів наданих міжнародними організаціями у вигляді допомоги. Джерелом фінансування реалізації відповідної програми повинні стати у тому числі й кошті державного бюджету.

Вище сформульовані висновки не вичерпують порушеної проблематики, а отже можуть бути уточнені та доповнені під час подальших наукових пошуків. Перспективними напрямами в організації наукових досліджень $є$ ті з них, змістове спрямування яких пов'язане з визначенням місця та ролі держави у забезпеченні функціонування системи вищої освіти України, а також з обґрунтуванням компетенції держави у забезпеченні ЗВО якості освітньої діяльності та якості вищої освіти загалом. Крім того, цікавим та вкрай важливим для використання потенціалів міжнародного досвіду в системі вищої освіти України є аналіз ефективності реалізації Урядом Китаю Проектів 211 та 985, особливо в частині отриманого державою ефекту, у тому числі й нематеріального.

Автор статті висловлює щиру подяку адміністрації Institute of International and Comparative Education at Beijing Normal University (China) в особі проф. Liu Baоcu за сприяння в організації опитування студентів, а також Uliana Furiv (University of Tampere, Finland) за безпосереднє його проведення на території Китаю.

\section{Список використаної літератури:}

1. Цілі сталого розвитку 2016-2030, Програма Розвитку ООН в Україні. URL: http:// www.un.org.ua/images/documents/3615/ цілі_web(2).pdf (дата звернення: 13.06.2019)

2. Середньостроковий план пріоритетних дій Уряду до 2020 року та плани пріоритетних дій Уряду. Діяльність : Програма діяльності Уряду. Урядовий портал : єдиний веб-портал органів виконавчої влади України. URL: https://www.kmu.gov.ua/ ua/diyalnist/programa-diyalnosti-uryadu/ serednostrokovij-plan-prioritetnih-dijuryadu-do-2020-roku-ta-plan-prioritetnihdij-uryadu-na-2017-rik (дата звернення: 13.06.2019)

3. Стандарти і рекомендації щодо забезпечення якості в Європейському просторі вищої освіти (ESG) / авт. тексту Європейська асоціація забезпечення якості вищої освіти. Київ : ТОВ «ЦС», 2015. 32 с.
4. Домбровська С.М. Державне управління вищою освітою в умовах трансформаційних змін : монографія. Харків : Вид-во «Оберіг», 2009. 176 с.

5. Курко М.Н. Адміністративно-правове регулювання вищої освіти в Україні : монографія. Харків : Вид-во Харків. нац. ун-ту внутр. справ, 2010. 376 с.

6. Розвиток системи забезпечення якості вищої освіти в Україні : інформаційно-аналітичний огляд / Добко Т. та ін; за заг. ред. С. Калашнікової та В. Лугового. Київ : ДП «НВЦ «Пріоритети», 2015. 84 с.

7. Любчук О.K. Теоретико-методологічні засади державного управління неперервною освітою в Україні та ії регіонах : монографія, Донецьк : СПД Куприянов В.С., 2010. 395 с.

8. Майборода С.В. Державне управління вищою освітою в Україні : структура, функції, тенденції розвитку (19171959 рр.) : Моногр. Київ : Вид-во УАДУ, 2000. 308 c.

9. Мороз В.М., Мороз С.А., Домбровська С.М. Французька модель підготовки науковопедагогічних кадрів: особливості розбудови та перспективи використання для розвитку трудового потенціалу вітчизняних ВНЗ. Вісник НУЦЗУ. Серія «Державне управління». 2016, Вип. 1 (4). С. 213-222.

10. Мороз В.М., Мороз С.А. Німецька модель підготовки науково-педагогічних кадрів : особливості розбудови та перспективи використання для розвитку трудового потенціалу вітчизняних ВНЗ. Теорія і практика управління соціальними системами. 2016. № 2. С. 87-96.

11.Огаренко В.М. Державне регулювання діяльності вищих навчальних закладів на ринку освітніх послуг : монографія. Київ : Вид-во НАДУ, 2005. 327 с

12. Садковий В.П. Державне управління в сфері формування освітніх стандартів підготовки фахівців цивільного захисту України : монографія. Харків : НУЦЗУ, КП «Міська друкарня», 2013. 240 с.

13. QS World University Rankings 2016, Rankings, QS Top Universities. URL: https:// www.topuniversities.com/university-rank ings/world-university-rankings/2015 (дата звернення: 13.06.2019)

14. QS World University Rankings 2019, Rankings, QS Top Universities. URL: https:// www.topuniversities.com/university-ra nkings/world-university-rankings/2019 (дата звернення: 13.06.2019)

15. Мороз С.А. Досвід Китаю у забезпеченні розвитку галузі освіти як підґрунтя для 
вдосконалення механізмів державного управління якістю вищої освіти України. Інвестиції : практика та досвід. 2019. № 9. С. 70-77.

16. Мороз С.А. Досвід Китаю щодо забезпечення якості вищої освіти через механізм ії інтернаціоналізації, Державне управління у сфері цивільного захисту: наука, освіта, практика : Міжнарод. наук.-практ. конф., 17-18 травня 2019 р. Харків, 2019. C. 44-46.

17. Sudman S, Bradburn N., Schwarz N. Thinking About Answers : The Application of Cognitive Processes to Survey Methodology. San Francisco : Jossey-Bass, 2010. $322 \mathrm{p}$.

18.Звіт про результати опитування вищих навчальних закладів України щодо стану розвитку внутрішньої системи забезпе- чення якості освітньої діяльності та якості вищої освіти, Міжнародні проекти університету : QUAERE, Львівський національний університет імені Івана Франка. URL: http://projects.Inu.edu.ua/quaere/ wp-content/uploads/sites/6/2018/03/ Звіт-про-результати-національного-опитування-щодо-внутрішніх-систем-забезпечення-якості.pdf (дата звернення: 13.06.2019)

19. Михальченкова Н.А. Китайские университеты в условиях трансформации государственной политики : ответ на вызовы глобализации. Власть, 2016. № 5. C. 75-87.

20. Hayhoe R. China's Universities 1985-1995: A Century of Cultural Conflict / Ruth Hayhoe. New York : Garland Publishing, 1999. $328 \mathrm{p}$.

\section{Moroz S. The competence of the state in ensuring quality control of provided by universities educational services: the analysis of opinions of students of Chinese universities of higher education}

Basing on the results analysis of the content of Standards and recommendations as for the quality assurance in the European area higher education, there was clarified a possibility of considering state on the level of one of the main stakeholders in the process of ensuring the quality of higher education. The vast majority of scientific researches on definition of the state competence in ensuring the quality control of providing by universities educational services was focused on studying of functioning of the Anglo-Saxon and European continental systems of higher education and was carried out mainly using purely theoretical methods of scientific knowledge. Such a vector in the organization of scientific research has left behind the model of higher education of the most developed countries of East Asia. At the same time, the results of the analysis of content and practice of such models have a great importance for the Ukrainian higher education system and can be used to improve the mechanisms of public administration of quality of domestic system higher education.

Realization of potential of international cooperation and the usage of practical methods of scientific learning gave author of the publication an opportunity to conduct a survey of students of the Institute of international and comparative education of Beijing pedagogical University (China) and find out their opinion on the power of state control over the quality providing of educational services by Higher educational institutes. The results of the analysis of the received answers indicate the fact that within the framework of the Chinese model of organization of higher education system, the state is the most competent and influential subject in the system of ensuring the quality of higher education. Among the respondents, only 5\% respondents support the view that the state should not perform strict control over the quality of higher education and the University activities. In its turn, $95 \%$ of the respondents are convinced that the state should perform strict control over the quality of educational services provided by Universities. Almost every fifth respondent (22\%) holds an opinion that it is necessary to introduce strict state control over provided by Universities quality of educational activities and the quality of higher education without taking into account the principles of University autonomy and academic freedoms. The article contains the justification of the obtained results through the prism of individual historical and cultural, social and political features of China's development. In addition, the article contains conclusions about the possibility of using the Chinese experience during the development of ways to improve the content and practice of the mechanisms of public administration of quality assurance of higher education.

Key words: state control over the quality of higher education, system of higher education in China, the survey of Chinese students, standards of quality of higher, mechanisms of public administration. 